\title{
Radiation and immunotherapy: united as one in the fight against cancer
}

In the early 2000s, radiation oncology treatments transformed from basic two-dimensional treatment plans to more complex treatment delivery where tumor directed therapy could be delivered with precise, high-dose radiation therapy (RT). Novel imaging modalities with magnetic resonance imaging (MRI), positron emission tomography/computerized tomography (PET/ CT), and 4-dimensional CT (4DCT) allowed radiation oncologists the ability to deliver more targeted treatment to achieve ablative doses to their target. Contemporary technologies incorporated sophisticated planning with intensity modulated radiation therapy (IMRT) and high-dose delivery with stereotactic body radiation therapy (SBRT or SABR), where local tumor control often reached $>90 \%$. The struggle however in oncology remained systemic disease control and to much excitement, in the past decade we have seen advances in immuno-oncology, a field many of us knew very little about.

Advances in immuno-oncology have led to promising treatments in multiple cancers yet some patients are still nonresponders and require additional combined agents, perhaps switching to second-line therapy, or potential combination with local modalities including RT. Despite overall encouraging data with immunotherapy studies to date, response rates are still lower than desired and durability of response is limited in many patients; combining systemic and local therapies may be the answer.

One answer may be combining immunotherapy with RT, which is being tested in numerous trials. The synergism between RT and immunotherapy is actively being studied and appears to be due RT induction of a systemic response known as the abscopal effect. RT has been shown to stimulate T-cell priming for the creation of tumor-specific antigens which can then travel to distant sites and attack cancer. A role for T-cells in the tumor response to RT was first discussed 50 years ago in mice experiments demonstrating reduced therapeutic efficacy in radiated mice that lacked T-cell machinery. In combination with immunotherapy which enhances the immune response, together this overactivation of the immune system to fight cancer may be the basis of remarkable clinical responses observed with RT and immunotherapy. Yet, as a field, we are far still from understanding the partnership between the two treatment modalities.

We are therefore pleased to have multiple experts of their respective fields review and discuss the current literature and ongoing trials combining RT and immunotherapy. After reading our edition, I hope you have a better overview of where the oncology field is heading and how together with both RT and immunotherapy, we can continue our efforts to treat and potentially cure our patients with cancer.

\section{Acknowledgments}

Funding: None.

\section{Footnote}

Provenance and Peer Review: This article was commissioned by the editorial office, Translational Cancer Research, for the series "Synergy in Action: Novel Approaches to Combining Radiation Therapy and Immunotherapy". The article did not undergo external peer review.

Conflicts of Interest: Both authors have completed the ICMJE uniform disclosure form (available at http://dx.doi.org/10.21037/ tcr-20-2636). The series "Synergy in Action: Novel Approaches to Combining Radiation Therapy and Immunotherapy" was commissioned by the editorial office without any funding or sponsorship. AA served as the unpaid Guest Editor of the series and serves as an unpaid editorial board member of Translational Cancer Research from Dec 2019 to Nov 2021. TR served as the unpaid Guest Editor of the series. The authors have no other conflicts of interest to declare.

Ethical Statement: The authors are accountable for all aspects of the work in ensuring that questions related to the accuracy or 
integrity of any part of the work are appropriately investigated and resolved.

Open Access Statement: This is an Open Access article distributed in accordance with the Creative Commons AttributionNonCommercial-NoDerivs 4.0 International License (CC BY-NC-ND 4.0), which permits the non-commercial replication and distribution of the article with the strict proviso that no changes or edits are made and the original work is properly cited (including links to both the formal publication through the relevant DOI and the license). See: https://creativecommons.org/ licenses/by-nc-nd/4.0/.

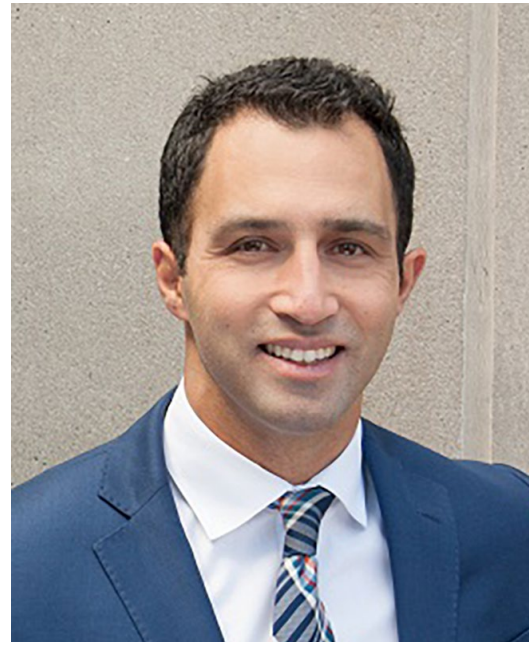

Arya Amini

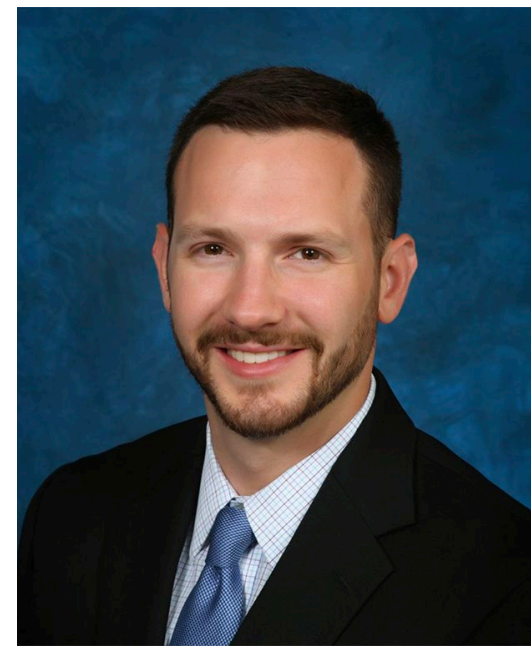

Tyler Robin

Arya Amini, $\mathbf{M D}^{1,2}$, Tyler Robin, $\mathbf{M D}^{1,2}$

${ }^{1}$ Department of Radiation Oncology, City of Hope National Medical Center, Duarte, California, USA; ${ }^{2}$ Department of Radiation Oncology, University of Colorado School of Medicine, Denver, Colorado, USA.

(Email:aamini@coh.org; Tyler.robin@ucdenver.edu)

Submitted Jul 31, 2020. Accepted for publication Aug 07, 2020.

doi: $10.21037 /$ tcr-20-2636

View this article at: http://dx.doi.org/10.21037/tcr-20-2636

Cite this article as: Amini A, Robin T. Radiation and immunotherapy: united as one in the fight against cancer. Transl Cancer Res 2021;10(5):2525-2526. doi: 10.21037/tcr-20-2636 